\title{
Creativity Through Technology In The English Classroom
}

\author{
Nancy Ann Zrinyi Long, (Email: longnz1 @earthlink.net), Bethune Cookman College
}

\begin{abstract}
First generation in college, low family income, and weak writing scores: This describes the students I teach at a historically black institute, Bethune Cookman College, in Daytona Beach, FL. These students dislike writing and hate grammar. Yet through technology, these students can be more motivated to write. With the use of a digital movie camera, students write and produce short films about stories they have written. A research paper becomes more interesting when students can add PowerPoint or film a background for their presentations. Even the digital photo camera becomes a source of interest as students make photographs of the people they are writing about for a biography assignment. Lessons become more meaningful when a projector with computer allows students to interact or watch examples of grammar or writing skills. So the basic grammar and composition class can be enhanced by the use of basic technology. Beyond the basic composition on the computer which is now the standard, students can use these other aspects of technology which encourage creativity, engagement, and motivation. Even for the professor, technology can inspire creativity. After having students help me videotape elderly people who talked about their lives here at the college and who knew the founder Dr. Mary McLeod Bethune, I spent the summer transposing these interviews and then researched and wrote a book called The Life and Legacy of Mary McLeod Bethune. Thanks to technology, I am now an author. Thus technology inspires students and teachers alike to aspire to higher levels of writing.
\end{abstract}

\section{INTRODUCTION}

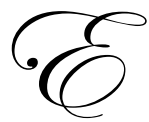

ach fall I choose students to be in my Title IV program for Student Support Services. The special criteria for selection is the following: first-generation college student, low-economic background, and developmental (remedial) level in writing and grammar according to scores on the college placement tests. These students are below college level in skills, but I place them in my college level Writing I course which offers a five day schedule and which combines the basic grammar and writing skills with the college level demands of literature and writing. This can be quite a challenging course to teach, and this is where adding technology has served as a motivational tool.

\section{DIGITAL PHOTO CAMERA}

I begin the semester with students interviewing each other and writing biographies. Using a digital photo camera, students photograph each other during the interviews. I print these photos and post them on what I call the "Writing Wall." Students type good copies of these biographies and the papers are displayed under the photos. Seeing their writing displayed under the photos seems to motivate students to work harder on the papers. I am amazed at how much time students spend just perusing the biographies of their peers.

Creative writing is enhanced by a photo to accompany the paper. Students are allowed to borrow the camera and take photos which relate to topics of their papers. They also help each other download pictures from the Internet for the covers of their papers. These papers are graded and revised, and the final versions are also put on display at the "Writing Wall." 


\section{DIGITAL MOVIE CAMERA}

The digital movie camera can be a miracle motivator to help students put their ideas onto film. For example, I assigned students to read the novel Kindred, which involves a young black woman being transported into the past days of slavery. The students then wrote creative essays about traveling into the past and encountering people or situations from the early days. The stories were shared with the class, and the class voted on the best stories. Groups were then formed to reenact the stories and create a ten-minute script based on the selected essay; this script was then acted out and videotaped with my movie camera. These films were later shown at a special assembly for the freshmen class as a "film fest." The student involvement and motivation in this project was truly inspiring. Whether they were writers or editors or actors, they truly got involved in this project. Again sharing the final product through technology with others encouraged motivation.

Last semester I had a class of 20 students who had not passed the strict standardized tests required in grammar and writing. It is an understatement to say these students returned to me totally demoralized and despondent. They felt as if they were failures. After a few days of pep talks and constant reminders that they had learned a lot and made great progress, but just not enough, I resorted to a heritage theme for the semester. I brought in some elderly people who had known Dr. Bethune, the founder of the college, and I had students videotape these speakers. I sent the students out into the community to videotape and write summaries of the life stories of these elderly. Then each of them had to interview, videotape or audiotape, and write about their own family members and the family history. Interest grew as the students created their own family history of stories and anecdotes of relatives. When they saw some personal purpose in the assignments, they wrote better. The passing rate of that class jumped to $80 \%$ by the end of the semester.

\section{COMPUTER AND PROJECTOR}

My students come to college with some basic computer skills, but most do not own a computer, and some are computer illiterate compared to peers from a better economic background. I have set up three computers in a hallway which are for student use. I borrow from the tech support department a computer and projector to add variation to the classroom lessons. For example, grammar exercises can be shown on the screen and students take turns coming to the computer to fix errors in grammar. If we are reading a particular short story or play, there is a vast array of video clips, audio readings, and biographies that can be downloaded and displayed to students to capture their interest before reading a selection.

Research papers can be a horrible experience for freshmen and instructor alike, but using the computer and projector for step-by-step procedure in the research paper process can make the assignment less painful. Furthermore students must do a PowerPoint presentation about what they learned in their research; PowerPoint adds a powerful motivation for both presenter and audience. Students enjoy creating these programs to share with their peers. Adding technology creates a touch of creativity and makes the research paper more interesting for all.

\section{PLAGIARISM CHECK}

Turnitin research paper site is a great resource. Research papers open up a new phase in technology as the instructor now has the tool to capture plagiarism in research papers and other essays. For a few years, I would type in a phrase from a suspicious essay using quotes; unfortunately I did catch some "downright" thieves who had simply copied and pasted an essay as their own work. Such surprise showed on their faces as they would sit and look me in the eyes and say these were their own essays, and I would pull out the printed websites with the same essays written by another author with a date much earlier than what the students had written. I had a mixed feeling of smugness at catching the plagiarism and sadness at the students' laziness and bravado to just download a paper or part of it and pawn it off as their own.

Now with Turnitin, the English teacher is even better armed in fighting the battle against plagiarism. My students must do the outline, works cited, and then a final draft of their research paper. They then sign on to the Turnitin.com site and submit their paper online. The Turnitin program shows the students what areas of the paper are 
incorrectly cited or need to be cited, and what needs to be reworded. This frees me as the instructor from worrying about the plagiarism; I can grade the paper now for content and grammar. It has truly been a liberating tool in the fight against plagiarism.

\section{BECOMING RESEARCHERS}

The Internet is the greatest tool for study, grammar practices, and research. Students can practice grammar skills by linking to the many sites sponsored by grammar handbook companies. These sites allow students to take tests, do grammar drills, and teach themselves in areas which they are weak. The Internet also provides a source of ideas for writing. One of the most exciting projects in my classroom has been the "Roots" project, where I have students do a family tree and trace their heritage. Several sites on the Internet provide help in genealogy. Two years ago students were writing about their families, and one girl came to class so thrilled. She had done a search on the computer and located her grandfather. This man had never seen his daughter, did not know he had a granddaughter, and had left the United States years before. The student found his name and an address in England. She told her mother and they called the man. He was the father; he decided to plan a trip to visit his newly found daughter and grand daughter during the next month. It was really exciting for this student, and for all of us in the class, to realize a writing assignment could lead to such meaningful results. Students really enjoyed researching their own family name and history, and they were motivated to write papers on what they had learned.

\section{BECOMING AUTHORS}

Audience is a key motivator to young writers. I require students to write journals, but I have found that students revise and edit much more when they post their journals on the website bulletin board. Posting their ideas for the others in the class to read and ponder makes the students truly think and write more carefully about their ideas and summaries. I do require a hard copy for me to edit and then the students can add it to their portfolio which is the compilation of all of their writings. The quality of these journals is enhanced when students know not just the teacher, but their peers, are reading their writing.

There is no better motivation for a student than to have a paper published. This past semester I helped several students email their papers to newspapers or magazines for publication. The thrill on their faces to see their letters to the editor in print was fulfilling to me. The biggest triumph this semester was when some students emailed their essays to a company which was printing a book on college student opinions. One of my students was chosen to be published and she spoke to an assembly and said that this recognition has changed her whole outlook about herself and her writing goals. I encourage my students to write poetry and journals in my class, but then enter these same writings for poetry contests and essay contests. With the internet, they can submit their work so easily. I tell them if they are working hard to write for my class, they might as well try to win some money or at least get their writing published to a bigger audience. Again technology helps students reach a larger audience, and this is motivation for them.

I myself have followed my advice. I personally began videotaping elderly people who knew Dr. Mary McLeod Bethune. After several years of taping, I transcribed the interviews and published three articles; this summer I took my laptop and while camping across the country, I wrote a biography on Dr. Bethune which was published in September. I never dreamed that I would write a book, but thanks to technology, I am an author. The book has been well received.

\section{GRADING}

The final benefit of technology for me is the computerized grading. I absolutely love setting the percentages on my program Maestro, and watching it calculate the grades according to tests, portfolio, attendance and finals. Thanks to the computerized grading, I have a printout for each student; they can see their averages in each area and understand the grade that they have earned. I can print or email the grades, and I have access to many reports, such as comparisons, averages, individual achievement, etc. The computer grading programs have eased the burden of accountability and grading for me as an instructor. 


\section{CONCLUSION}

Therefore, technology over the past five years has liberated me as a teacher and made my job much easier. Technology provides a tool to motivate the underachieving, low-skilled student who is afraid of writing and who hates grammar. Working with minority students at a historically black college, I find that these students especially need technology which engages their interest and allows them to learn in untraditional ways. If every student, rich or poor, could have his own computer and have access to the Internet, I believe the research, writing skills, grammar, and literary level of every students would be enhanced. As for the English instructor or any instructor, taking advantage of the multi-sensory instruction available with technology enhances the instructor's ability to motivate and captivate students; it makes learning more fun and interesting for students, and education becomes more relevant.

\section{NOTES}

